\title{
The Strong and the Fat Heart in the Old Testament: Does God Hearten the Heart?
}

\author{
HANS-GEORG WÜNCH (UNISA)
}

\begin{abstract}
This article looks at the different Hebrew terms used in connection with the stubbornness of the heart. Is there a difference between "making the heart strong" and "making the heart fat"? And what other verbs are used in these contexts where God is active in the hearts of human beings? It also asks how these divine actions are related to the actions of the respective humans. To do this, we will first look at the anthropological meaning of the term "heart" in the OT and then relate this meaning to the different verbs used for God's actions. The article starts with the assumption of a synchronic reading of the OT and also tries to answer the question of whether or not there is also some change or development of the terms used for God's working in the hearts of human beings throughout the different books of the OT.
\end{abstract}

KEY WORDS: Stubbornness of the heart; deity and human actions; synchronic exegesis; sovereignty; Hebrew language.

\section{A INTRODUCTION}

Some years ago I was on a trip to Israel with a group of German tourists. We drove through Jerusalem in a bus and I saw a sign at a road construction ahead. It was the common sign for "attention": a triangle with red borders. In it I could read the Hebrew words שים לב - "set a heart." At first I was not sure if I really understood the Hebrew words correctly because I could not make sense of them. So I asked the driver what they meant. He told me the words just meant "be aware of danger."

As Germans we would not use the term "heart" in such a context. We could use "eyes" (in the sense of "open your eyes") or "brain" (in the sense of "think about the danger"), but we certainly would not use "heart." Interestingly, this Modern Hebrew term resembles the OT use of "heart." For example, in Exod 9:21 God speaks about those who do not "set their heart upon the word of YHWH," or in Job 1:8 God asks Satan: "Did you not set your heart upon my servant Job?"

\footnotetext{
* Article submitted: 3/01/2017; peer-reviewed: 9/02/2017; accepted: 20/02/2017. To cite: Hans-Georg Wünch, "The Strong and the Fat Heart in the Old Testament: Does God Hearten the Heart?" Old Testament Essays 30/1 (2017): 165-188. Doi: http:// dx.doi.org/10.17159/2312-3621/2017/v30n1a10
} 
To "set one's heart upon" therefore means to concentrate one's attention firmly upon something or someone. In a very negative sense this is used in Zech 7:12, where Israel is depicted as a people who have set their hearts as firm as a diamond upon not hearing the word of God.

This article is about another aspect of the heart in the OT: the so-called "hardening of the heart." There are mainly three sections in the OT where this theme is explored - in the Exodus narrative, in the calling of the prophet Isaiah and in the book of Jeremiah. In the Exodus narrative we read about the "strong" and "heavy" heart of Pharaoh. Isaiah is called to "make fat" the heart of his people and Jeremiah speaks about the "stubbornness" of the heart of Israel. Since there are different Hebrew words used in these three instances we will look at them in three separate steps. The main question is: what is God doing to the heart of the humans? Does he make them unable to hear or repent, even against their own will? And how should we translate these verses?

We will start with a study of the "heart" in the OT. What aspects of the human personality are connected with this anthropological term? Is "heart" the correct translation? We will then turn to the Exodus narrative where the theme of the "hardening of the heart" is explored at great length (we will later answer the question if this expression fits the Hebrew terms). The Exodus narrative is in fact the only story in the OT which explores the theme of the "hardening" of human beings in greater detail. ${ }^{1}$ We will look at the different verbs used in connection with the heart in these passages.

Finally we will look at the passage in Isa 6:10 where another verb is used in connection with the heart. Since this passage is cited and often referred to in the NT, it is very important to understand its meaning correctly. Röhser points out that the Exodus narrative and Isa 6:9-10 may be understood as two different models of "hardening." $\mathrm{We}$ will explore this later in this article.

Then we will look at a term used especially by Jeremiah to denote stubbornness or a hardened heart. We will see if this term fits into the concept of "hardening of the heart" which will be developed from the Exodus narrative and Isa 6:10.

Finally, we will try to answer the following question: Is there is a common theme of "hardening" in the OT and how can these various terms and passages be integrated into this overall theme?

1 Edgar Kellenberger, Die Verstockung Pharaos: Exegetische und auslegungsgeschichtliche Untersuchungen zu Exodus 1 - 15, BWANT 171 (Stuttgart: Kohlhammer, 2006), 16.

2 Günter Röhser, Prädestination und Verstockung: Untersuchungen zur frühjüdischen, paulinischen und johanneischen Theologie, TANZ 14 (Tübingen, Basel: Francke, 1994), 40. 
Wünch, "The Strong and the Fat Heart," OTE 30/1 (2017): 165-188

\section{B THE "HEART" - THE CENTRE OF DECISION, WILL, AND COURAGE}

Every culture and language uses anthropological terms as symbols for conceptual ideas like love, courage, decision or personality. If a German man, for instance, tells a woman that he has lost his heart to her, he is saying that he loves her. It is important to understand these anthropological terms correctly as well as the idioms in which they occur.

One of the most foundational works on the anthropology of the OT was completed by Wolff in 1973. His book was recently revised and amended by Janowski ${ }^{3}$ which shows that his work has not lost its relevance and still represents the current state of OT scholarship. Since the main focus of this article is the understanding of the different aspects attributed to the "heart" in the OT, we will not go too deep into the understanding of the anthropological term לביב. Instead we will start with a brief summary of Wolff's findings.

לֵ is by far the most important anthropological term in the OT. It occurs 858 times $^{4}$ and therefore is the most frequently used anthropological term. ${ }^{5}$ Most of the passages connect the with different aspects of the inner life such as "feelings," "emotionality" and "sensibility." This understanding is not far removed from the German or English understanding of the term "heart." Included in this use of לִ are passages that refer to "courage" or its counterpart "fear." When courage is lacking, the heart is like leaves in the wind (Isa 7:2), it becomes soft and weak (Isa 7:4; Deut 20:8), dissolves like wax (Deut 8:20; Ps 22:15) or water (Josh 7:5). ${ }^{7}$ The importance of this particular understanding of לֵ will become clearer later in this discussion. Finally, לֵ may also refer to the "desire" of a human being. ${ }^{8}$

3 Hans W. Wolff and Bernd Janowski, Anthropologie des Alten Testaments, Mit zwei Anhängen neu herausgegeben von Bernd Janowski, 1st ed., (Gütersloh: Gütersloher Verl.-Haus, 2010).

4 Risto Lauha, Psychophysischer Sprachgebrauch im Alten Testament: Eine strukturalsemantische Analyse von רוח und נפש (Helsinki: Suomaleinen Tiedeakademia, 1983), 46.

5 Wolff and Janowski, Anthropologie, 75. Frederik Hendrik von Meyenfeldt states in his doctoral thesis, that the term לִ "does not just denote a physical or spiritual part of Man. LEB (LEBAB) represents the whole person." Cf. Frederik Hendrik von Meyenfeldt, Het hart (leb, lebab) in het Oude Testament (Leiden: Brill, 1950), 218.

6 Wolff and Janowski, Anthropologie, 82.

7 Wolff and Janowski, Anthropologie, 82.

8 Wolff and Janowski, Anthropologie, 82-84. 
However, according to Wolff, these meanings are not the most significant ones of לֵ. The most important meaning is "reason" or "thinking." We usually tend to attribute intellectual and rational functions to the head or more specifically to the brain. ${ }^{10}$ Wolff therefore recommends translating the word לִ in these instances with "spirit" rather than "heart."11 This can be seen most clearly in Deut 29:3 (NAB):

But the LORD has not given you a heart to understand, or eyes to see, or ears to hear until this day.

As the eyes are designed to see and the ears are designed to hear, so the heart is designed to understand. Wolff concludes: "Ganz allgemein kann 'Herz' in solchen Zusammenhängen mit 'Verstand' übersetzt werden..."12

From this understanding of לִ as "mind" it is not far to the next step of understanding it as "decision." 13 According to Wolff, the transition from the functions of the mind to the activities of decision-making is fluent. ${ }^{14}$ It is in this context that Wolff also speaks of the hardening of the heart: "Am Tatort der Willensentschlüsse ereignet sich auch die Verstockung: das Herz verhärtet sich, wird unempfindlich und unbeweglich." 15 We will discuss later whether this is really what a "strong" or "heavy" heart means.

It is interesting to see how this understanding of the anthropological term לֶב also corresponds with the understanding of the "heart" in ancient Egyptian culture as convincingly demonstrated by Assmann. ${ }^{16} \mathrm{He}$ asserts that the "heart" in Egypt was understood as being the centre of the personality. ${ }^{17}$ It is therefore important to make this "heart" strong, as the story of Amenemope shows. In this classical story of an Egyptian Robinson Crusoe, the shipwrecked man receives the following prophecy: "Wenn du tapfer bist, und wenn dein

9 Wolff and Janowski, Anthropologie, 84-90. Franz J. Stendebach: "Im Werk des Jahwisten ist die nefesch niemals Subjekt speziefisch 'geistiger' Funktionen: Diese Rolle kommt vielmehr dem Herzen zu." Cf. Franz J. Stendebach, Der Mensch ... wie ihn Israel vor 3000 Jahren sah (Stuttgart: KBW, 1971), 131; cf. also Lauha, Psychophysischer Sprachgebrauch, 50.

10 Wolff and Janowski, Anthropologie, 84.

11 Wolff and Janowski, Anthropologie, 84.

12 Wolff and Janowski, Anthropologie, 90. Comp. also Willem A. M. Beuken, Jesaja

1-12, HThKAT 19/1 (Freiburg im Breisgau: Herder, 2003), 176.

13 Wolff and Janowski, Anthropologie, 90-96.

14 Wolff and Janowski, Anthropologie, 90.

15 Wolff and Janowski, Anthropologie, 92.

16 Jan Assmann, "Zur Geschichte des Herzens im Alten Ägypten,” in Die Erfindung des inneren Menschen: Studien zur religiösen Anthropologie, ed. Jan Assmann, SVfR 6, (Gütersloh: Gütersloher Verl.-Haus Mohn, 1993). 81-113.

17 Assmann, Erfindung, 84. 
Herz fest ist, dann wirst du deine Kinder umarmen, deine Frau küssen und dein Haus wiedersehen."18

If we want to understand the passages speaking about the "hardening of the heart" in Exodus or the "fat heart" in Isaiah, we will have to keep in mind these basic findings that Wolff and others have made. The "heart" is the centre of personality. In most instances it depicts the concept of will, mind and decision. Almost every recent commentary or theological book on anthropological issues confirms these ideas. Nevertheless, it often seems that when it comes to the themes of hardening the "heart" or the fat "heart," the translation "heart" continues to be used - which tends to restrict the understanding of לב. to its emotional meaning. Instead it would be better to understand the Hebrew term לב as the "centre of courage and decision." We will now look at the Exodus narrative and the verbs used in the context of "hardening the heart" in these passages.

\section{THE VERBS USED IN THE EXODUS NARRATIVE}

The main verb used in the Exodus narrative to describe what usually is called "hardening of the heart" is the verb חז, which means "to be strong." 19 It occurs 12 times in these chapters together with the noun לבי. It is used eight times with God as the subject, and four times the heart of Pharaoh itself is the subject of "hardening." The first occurrence is found in Exod 4:21 where God announces to Moses that he will "harden" the heart of Pharaoh so that he will not let the people of Israel go. Then we find three instances where it is the heart of Pharaoh itself which "hardens" against God's will (Exod 7:13, 22; 8:15). In Exod 9:12 it is God again who "hardens" the heart of Pharaoh. Then, in 9:35, the heart of Pharaoh "hardens" and, finally, in 10:20 and 27, 11:10, 14:4, 8 and 17 it is God once more who "hardens" the heart.

The second verb which is also used quite often in the Exodus narrative to describe the "hardening of the heart" is כבד, which means "to be heavy." occurs six times in reference to the heart of Pharaoh. In five instances it is Pharaoh himself, who either makes his heart "heavy" (Exod 8:11, 28; 9:34), or whose heart is or becomes "heavy" (Exod 7:14; 9:7). Only in Exod 10:1 is it God who makes the heart of Pharaoh and his servants "heavy."

\footnotetext{
18 Assmann, Erfindung, 85.

19 Wilhelm Gesenius, et al., Hebräisches und aramäisches Handwörterbuch über das Alte Testament, 18th ed. (Heidelberg: Springer, 2013), 335. Although Gesenius of course is a book written in German, the Hebrew terms in this article are cited in their English translation.
}

20 Gesenius et al., Handwörterbuch, 522. 
The third verb used in the context of the "hardening of the heart" in the Exodus narrative is קשה ("to be hard, heavy"). ${ }^{21}$ It occurs only twice. In Exod $7: 3$ it is God who will make the heart of Pharaoh "hard" so that he will not listen to God and react positively to his signs and wonders. The second occurrence is found in 13:15 where the noun לב is missing. The text says: "Then it happened that Pharaoh made hard (hiphil) ... not to send us away ..." Thus, although the object of the hardening is missing, this passage can also be seen as belonging to the theme of the "hardening of the heart."

These three verbs are used more or less synonymously, ${ }^{22}$ although I believe they show different aspects, as we will see later. All together there are 20 passages in the Exodus narrative where the theme of "hardening of the heart" occurs. Kaiser writes:

In all there are ten places where "hardening" of Pharaoh's heart is ascribed to God $(4: 21 ; 7: 3 ; 9: 12 ; 10: 1,20,27 ; 11: 10 ; 14: 4,8,17)$; but it must be stated just as firmly that Pharaoh hardens his own heart in another ten passages $(7: 13,14,22 ; 8: 15,19,32 ; 9: 7,34,35$; $13 ; 15)$. Thus the hardening is as much Pharaoh's own act as it is the work of God. Even more significant is the fact that Pharaoh alone is the agent of the hardening in the first sign and in the first five plagues. Not until the sixth plague ... is it stated that God actually moves in and hardens Pharaoh's heart $(9: 12) \ldots{ }^{23}$

We will start by looking at each of the three verbs to see how they are used in these passages and what exactly they are describing in connection with the "heart."

\section{1 חז}

As mentioned above, the basic meaning of the verb חז in qal is "to be strong." 24 In piel it means "to make something strong," "to repair something." It can also mean "to give strength to somebody, strengthen him." ${ }^{25}$ In this context Gesenius writes that it can also mean "to harden somebody's heart."26

21 Gesenius et al., Handwörterbuch, 1198.

22 Cf. Douglas K. Stuart, Exodus, NAC 2 (Nashville: B\&H Publishing Group, 2006), 147. See also Helmut Utzschneider, Wolfgang Oswald, and Shimon Gesundheit, Exodus 1-15: Deutschsprachige Erstausgabe, 1st ed., IEKAT 2/1 (Stuttgart: Kohlhammer Verlag, 2013), 195.

${ }^{23}$ Walter C. Kaiser, "Exodus," in Genesis - Leviticus, ExBC 1, ed. Tremper Longman and David E. Garland (Grand Rapids, MI: Zondervan, 2008), 382.

24 Gesenius et al., Handwörterbuch, 335.

25 Gesenius et al., Handwörterbuch,336.

26 Gesenius et al., Handwörterbuch,336. 
In hiphil it means "to make strong," "to seize, hold" or "to be strong." 27 The hithpael is used in the sense of "to make oneself strong" or "to take courage." 28

If we examine these different aspects of קז, we can easily see that this word usually denotes something positive. It speaks about courage and strength. It seems strange therefore that together with the noun "heart" it should suddenly change into something negative in the sense of making someone unable to react as he would otherwise like to. Can it really mean that God will "harden Pharaoh's heart"? The English term "hardening" can easily be understood as something happening to the human "heart" ("will" or "centre of decision making") from the outside. Could it be true, as Enns claims, that God prevents "Pharaoh from acting in such a way as to save his own neck and the neck of his kingdom"? ${ }^{29}$ Similarly, Wakely ${ }^{30}$ argues that one should use the term "obdurate" or "callous" when the qal or piel of חis used together with the noun "לn "ל. However, how can that be when Wakely himself points out that there are instances where חזב המץ is used together with אמק in which case it means that "a faithful worshipper is urged to be resolute and to let his heart take courage"? 32

Hesse also agrees that basically has a positive meaning, ${ }^{33}$ but continues to assert that it is used in a special sense when combined with the noun לֵ.

Hier ist von einer positiven Bedeutung keine Rede; in diesem Fall ist auch nicht von der Grundbedeutung "stark werden (sein)," sondern von der abgeleiteten Bedeutung "hart werden (sein)" auszugehen. Ein hart gewordenes Herz ist für äußere Einflüsse unempfänglich geworden. Damit ist gesagt: Die ganze Person, deren Herz "hart" geworden ist, zeigt sich unzugänglich, verhärtet, verstockt. ${ }^{34}$

However, Propp in his recent commentary on the book of Exodus questions this assumption. He writes:

27 Gesenius et al., Handwörterbuch,336.

28 Gesenius et al., Handwörterbuch,336-337.

29 Peter Enns, Exodus, NIVAC (Grand Rapids, MI: ZondervanPublishingHouse, 2000), 130.

30 Robin Wakely, "חז," NIDOTTE Vol. 2: 68-70.

31 "The q. occurs with the nom. lēb, heart ..., with the meaning be callous or obdurate," cf. Wakely, NIDOTTE Vol. 2: 68 and, "When the obj. of the pi. is leeb, heart ... or pānîm, face ..., the reference is to obduracy," cf. Wakely, NIDOTTE Vol. 2: 70 .

32 Wakely, NIDOTTE Vol. 2: 67.

33 Franz Hesse, "hāzaq," in: Bottwerweck/Ringgren, ThWAT. Vol. 2: 847-848.

34 Hesse, ThWAT Vol. 2: 856. 
The traditional translation "harden" is misleading, since we use "hard-hearted" to connote cruelty. The Hebrew does not mean "I will make Pharaoh cruel," but rather "I will strengthen his resolve" or "make him stubborn" ...

In Isa 35:4 God admonishes the Israelites not to fear but to "strengthen"

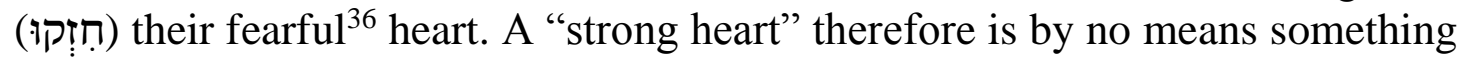
bad in itself. Recently Kellenberger wrote an inspiring book on the "hardeningtheme" in Exodus. ${ }^{37}$ In his book Kellenberger elaborates on a theory he formulated in an article published in $2002,{ }^{38}$ namely:

חזק wertet stets negativ, hingegendsätzlich positiv konnotiert, und כבד ist ambivalent in seinen Auswirkungen auf die Menschen. ${ }^{39}$

The Hebrew verb חזק has a basically positive connotation throughout the whole OT. ${ }^{40}$ It is used in the sense of to "strengthen" or "encourage" someone. This is also true of Qumran. ${ }^{41}$ When used in piel (as is often the case in the Exodus narrative), it means "eine Ermutigung zu einer Überlegenheit." 42

As already shown, חזק occurs 12 times together with the noun לִ in the Exodus narrative. The eight occurrences where God is the subject are all found in the piel-form of the verb, while the four occurrences where the heart of Pharaoh is the subject are all in qal. ${ }^{43}$ The first passage in Exod 4:21 is part of God's instruction to Moses. Here God announces that he will give Pharaoh a strong will and courage so that he will be able to carry out his decision, namely to refuse to let Israel go. Then we read that indeed Pharaoh made a firm

35 William H. C. Propp, Exodus 1-18: A New Translation with Introduction and Commentary, 1st ed., AYB 2 (New Haven: Yale Univ. Press, 2010), 217.

36 The Hebrew speaks of a "hasty" heart. The picture of a heart, which beats quickly because of fear, seems to be behind this diction.

37 Kellenberger, Die Verstockung Pharaos.

38 Kellenberger first published his ideas in an article entitled Edgar Kellenberger, "Theologische Eigenarten der Verstockung Pharaos in Ex 4-14," TZ 58 (2002): 109113.

39 Kellenberger, "Theologische Eigenarten," 110.

40 Kellenberger, Die Verstockung Pharaos, 34-36.

41 Kellenberger, Die Verstockung Pharaos, 36.

42 Kellenberger, Die Verstockung Pharaos, 37.

43 According to Kellenberger, this is logical: "Das $P i^{\prime}$ 'el ist deutlich resultative: 'JHWH stärkt/ermutigt Pharaos Herz' ... Dabei ist ... zu beachten, dass das Pi'el stets eine akzidentielle Aussage macht, d.h. das menschliche Herz ist nicht von sich aus bereits entspricht innerer Logik, dass bei den $P i$ 'el-Belegen stets JHWH Subjekt ist, wogegen es nie heisst, dass Pharao selber sein Herz stark gemacht habe." Kellenberger, Die Verstockung Pharaos, 46. 
decision ("heart") not to listen to God's order (Exod 7:13, 22; 8:15). This is underlined in Exod 9:12 where God strengthens this decision of Pharaoh. Finally, we read once more in Exod 9:35 that it is again Pharaoh's firm decision not to listen to God's command. From then on we only find passages speaking about God encouraging Pharaoh to stick to his decision (Exod 10:20, $27 ; 11: 10 ; 14: 4,8,17)$. The more suffering Pharaoh and his people had to endure, the more he needed God's support to stick to his decision.

This means that God is not acting against Pharaoh, forcing him to do something he does not want to do. ${ }^{44}$ Rather, he is strengthening Pharaoh in his own decision to not let Israel go. ${ }^{45}$ In their recent commentary on Exodus, Utzschneider and Oswald write: "In diesen Wendungen ... kann man die Herzensverfestigung des Königs im Sinne einer Stärkung und Ermutigung verstehen." 46 Kellenberger believes that this has a "paradoxical character" since YHWH encourages Pharaoh to follow through with something "was dem göttlichen Anliegen scheinbar zuwiderläuft." 47 Kellenberger shows that all this has a clear goal: Pharaoh and the Egyptians (and of course also Israel) should recognize (ידע) that YHWH alone is God. ${ }^{48}$ Ultimately it is God who directs and leads everything. ${ }^{49}$

\section{2}

כבד

The second verb used in the Exodus narrative to describe the "hardening of the heart" is the word כבד. Its basic meaning in qal is "be heavy." "50 It can also be used in a figurative sense as "being honoured" or "being respected." 51 In niphal it is only used in the figurative sense (either passive or reflexive). ${ }^{52}$ The same is true for piel, pual and hithpael. In 1 Sam 6:6 (where it is piel) it means, according to Gesenius, "to harden" or "to be obdurate." 53 In hiphil it also

44 Georg Fischer, Dominik Markl, and Christoph Dohmen, Das Buch Exodus, ed. Christoph Dohmen, NSKAT 2 (Stuttgart: Verl. Kath. Bibelwerk, 2009), 74.

45 John I. Durham, Exodus, WBC 3 (Waco, TX: Word Books, 1987), 86.

46 Utzschneider, Oswald, and Gesundheit, Exodus 1-15, 198.

47 Kellenberger, Die Verstockung Pharaos, 46.

48 Kellenberger, Die Verstockung Pharaos, 83-86.

49 David M. Gunn, "The 'Hardening of Pharaoh's Heart': Plot, Character and Theology in Exodus 1-14," in Art and Meaning: Rhetoric in Biblical literature, ed. Alan J. Hauser, David J. A. Clines, and David M. Gunn, JSOTSup 19 (Sheffield: JSOT Press, 1982), 88-89.

50 Gesenius et al., Handwörterbuch, 522.

51 Gesenius et al., Handwörterbuch, 522.

52 Gesenius et al., Handwörterbuch, 522.

53 Gesenius et al., Handwörterbuch, 523. 
means "to make heavy," "to honour someone" or "to weight someone down." According to Gesenius, it can also mean "to make someone obdurate." 54

John Collins claims that "weight' is the central meaning of which the other uses are applications." 55 Dohmen and Stenmans claim that when it refers to a part of the human body being "heavy," it means that this part becomes unable to perform its usual functions. ${ }^{56} \mathrm{We}$ will have to answer the question if this also applies to a "heavy heart." Collins himself thinks that, "When the heart is called $k \bar{a} b \bar{e} d$, it is unresponsive or hard to its proper role of prompting humans to obey God."57

Making the heart "heavy" is usually something a person does to his own heart. As already mentioned, there are six occurrences of the word כבד together with לֵ in the Exodus narrative. ${ }^{58}$ In two passages the heart of Pharaoh is the subject and כבד is used in qal: "the heart of Pharaoh was/became heavy" (Exod $7: 14 ; 9: 7)$. Three times the hiphil form is used where Pharaoh himself is the subject: "Pharaoh made his heart heavy" (Exod 8:11, 28; 9:34). Finally, the hiphil form is used once with YHWH as subject. YHWH tells Moses that he has made the heart of Pharaoh heavy (Exod 10:1). In this context it should be noted that a hiphil form can only be used when there is nothing which comes into the heart from the outside. It is already in the heart of Pharaoh to do it this way. Kellenberger therefore translates the phrase with “... dem Herzen ein EigenGewicht (bzw. Autorität) geben." 59

Again we see that it is first Pharaoh who actively makes his heart heavy. Only after he has done this several times does God actively do the same: he makes the heart of Pharaoh heavy. Again God's work is not something against the will of Pharaoh, but what he does strengthens Pharaoh and his decision not to let Israel go.

54 Gesenius et al., Handwörterbuch, 523.

55 C. John Collins, "כבד," NIDOTTE Vol. 2: 577.

56 Christoph Dohmen and Peter Stenmans, "kābed $\underline{d}, "$, in: Botterweck/Ringgren, ThWAT Vol. 4: 19. Hesse believes that Gen 48:10 shows how the meaning "obduracy" developed. The eyes of Jacob are "heavy." This leads to the inability to see. In the same way he thinks that the "heavy" heart is a heart which is unable to respond. Cf. Franz Hesse, Das Verstockungsproblem im Alten Testament: Eine frömmigkeitsgeschichtliche Untersuchung, BZAW 74 (Berlin: Töpelmann, 1955), 7, comp. also Carl F. Keil, Genesis und Exodus, $3^{\text {rd }}$ ed. (Giessen u. a.: Brunnen-Verl., 1983), 382-383.

57 Collins, NIDOTTE Vol. 2: 578.

58 Only here do we find the combination of כבד together with (Kellenberger, Die Verstockung Pharaos, 40). Three times the ears are called כבד (Isa 6:10; 59:1; Zech $7: 11$ ), once we find the "heavy eyes" of Jacob (Gen 48:10) and also once the heavy tongue of Moses (Exod 4:10) (comp. Kellenberger, Die Verstockung Pharos, 41).

59 Kellenberger, Die Verstockung Pharaos, 46. 
Kellenberger shows that כבד may either be positive or negative for the human being. ${ }^{60}$ There seems to be some ambiguity depending on the context in which the word is used, ${ }^{61}$ at least when it comes to the effect or end result of the hardening. The human heart is often viewed critically in the OT; it is "evil from youth on" (Gen 8:21). If this human heart therefore receives authority to carry out its own will, this may very well be ultimately something extremely negative. ${ }^{62}$ Interestingly, in Exod 9:34 the "heavy heart" of Pharaoh is seen as a result of his continued sinning. Nevertheless the translation "hardening" should not be used for כבד, as Kellenberger makes clear, ${ }^{63}$ since this suggests that there was something from the outside influencing Pharaoh against his own will.

\section{$3 \quad$ קששה}

The third verb in the Exodus narrative used to describe the "hardening of the heart" is the verb קששה. Its basic meaning is "to be hard."64 In qal it means "to be hard," "to be heavy" or "to be fierce." 65 In hiphil the meaning is "to harden," "to be stubborn," "to make heavy." It is only used once in niphal ("to be depressed," Isa 8:21) and once in piel ("to have a rough ride," Gen 35:16). ${ }^{66}$

The verb appears 29 times in the OT, ${ }^{67}$ mostly in connection with the neck (having a "hard neck" means to refuse to return from one's way (2 Kgs 17:14; Jer 7:26; 17:23; 19:15; Prov 29:1; Neh 9:16-17, 29; 2 Chr 30:8; 36:13). Together with the "heart" we find it only four times (Exod 7:3; Ps 95:8; Prov 38:14 and Ezek 3:7 [as adverb]). Walker and Swart write: "The word $q \hat{s} h$ is used in the sense of stiff-necked ... Its use in connection with Pharaoh's heart has been especially noted." 68

That this special use in connection with Pharaoh's heart has been "especially noted" seems somewhat strange since קשה only appears twice in the Exodus narrative and only once (in Exod 7:3) it is used together with the noun and the subject is God. God explains to Moses that he will make the heart of Pharaoh "hard" so that he will not hear. The second time it is used in Exod 13:15, but without the noun לֵ. Here Moses is explaining the law of the

60 Kellenberger, "Theologische Eigenarten," 111; Kellenberger, Die Verstockung Pharaos, 39.

61 Kellenberger, Die Verstockung Pharaos, 41.

62 Kellenberger, Die Verstockung Pharaos, 47.

63 Kellenberger, Die Verstockung Pharaos, 178.

64 Larry Walker and Ignatius Swart, "קשה," NIDOTTE Vol. 3: 997-99 (998). Cf. also

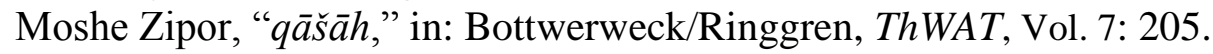

65 Gesenius et al., Wörterbuch, 1198.

66 Gesenius et al., Wörterbuch, 1198.

67 Walker and Swart, NIDOTTE Vol. 3: 998.

68 Walker and Swart, NIDOTTE Vol. 3: 998. 
offering of the first-born. In this context he speaks about Pharaoh himself being קשהה.

Kellenberger thinks that this verb is the only one of the three verbs used in the context of the "hardening of the heart" which is clearly negative in its meaning. ${ }^{69}$ There is no passage in the OT where being קשה can mean something positive. ${ }^{70}$ Although this verb only occurs once in the Exodus narrative together with לִ (Exod 7:3), its clearly negative meaning has served throughout the history of exegesis as the basis for understanding the other two

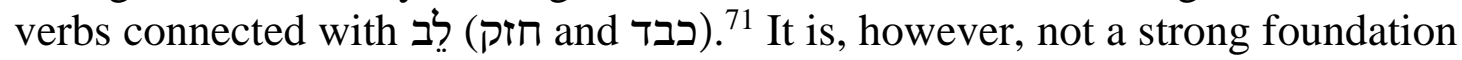
upon which to make conclusive deductions.

\section{Conclusion}

There are two conclusions to be made at this point:

(i) From our research on the meaning of the three Hebrew verbs, it seems to be clear that the term "hardening" is inadequate, at least when it comes to the verbs כבד חבד and The English term "hardening" can easily be understood as something happening to the human "heart" ("will" or "centre of decision making") from the outside, which results in making the human being unable to respond as he or she would otherwise wish to do. This is even truer when it comes to terminology like "callousness" or "obduracy." The Hebrew terms basically describe something positive: self-reliance, strong courage, a fierce decision. ${ }^{72}$

As already stated, the three terms כבד ,חזק and pשה are more or less used synonymously. However, there is a subtle distinction! When we understand לֶב to be "the centre of courage and decision" (as argued above) the three terms can be understood as three aspects of the same theme. חiscribes the activity of the human will. There is a decision in the mind which becomes stronger. The human being becomes courageous to follow through with this decision. This causes his mind to become heavy (כבד), giving a decision weightiness, so that it cannot be easily discarded. כבד therefore refers to the quality of the human will. From an outside perspective this "heavy" will (קשה) can be seen as something strong and immoveable. קשה therefore refers to the effect that the strong and heavy will of the human being has when it comes into conflict with the will of others or God.

69 Kellenberger, "Theologische Eigenarten," 110.

70 Kellenberger, Die Verstockung Pharaos, 38. This of course does not mean that it just cannot be used in a positive sense. There just is no evidence for it in the OT.

71 Kellenberger, "Theologische Eigenarten," 111.

72 Christoph Dohmen, Exodus 1-18, ed. Erich Zenger and Ulrich Berges, HThKAT 2/1 (Freiburg: Herder, 2015), 239. 
Whether or not these terms describe a condition with positive or negative aspects cannot be determined by the terms themselves (with the possible exception of קששה). It must instead be deduced from the situation in which the human will is strong and courageous. In the case of Pharaoh and the Egyptian people their mind and will are strong in disobeying God - therefore it is of course to be seen as a negative example of the human will being obstinate against God. When the Philistines discussed what to do with the arc of the covenant which had come to be in their territory, their priests admonished them to learn from the Exodus narrative:

Why should you become stubborn (lit.: "make your heart heavy," כבד (כ), the way the Egyptians and Pharaoh were stubborn (lit. "made their hearts heavy")? (1Sam. 6:6)

A strong and heavy "heart" can be something very good when it comes to the decision to follow God and his word. On the other hand it will be disastrous when it works against God and his word.

(ii) Nowhere in the Exodus narrative is God presented as acting against the will of Pharaoh or the Egyptians. Rather, the narrative describes a battle between God's will and that of Pharaoh. Before the conflict between YHWH and Pharaoh even really begins, God makes clear that he will strengthen (חזק) the decision of Pharaoh to not let the people of Israel go (Exod 4:21). God himself will make Pharaoh's will harder (קשה), so that he will not falter in his decision (Exod 7:3), he will give weight (כבד) to Pharaoh's decision (10:1). It was YHWH's intention that the battle between himself and Pharaoh would go all the way to the end. ${ }^{73}$

When the conflict starts, it is Pharaoh himself who is presented as the active participant. His decision was strong (חזק - Exod 7:13) and heavy (כבד - Exod 7:14). This is repeated again and again (Exod 7:22; $8: 11,15,28 ; 9: 7,34,35)$, until the active participant changes and God becomes the subject of these verbs. By Exod 9:12 God announces that he will strengthen (חז) the decision (heart) of Pharaoh. This is repeated in Exod 10:1 with the word כבד and then in 10:20, 27; 11:10; 14:4, 8, 17 with the word חזק. We can therefore say that what was first stated by God himself then shows as something Pharaoh had in his mind and will. And as the battle between YHWH and Pharaoh drew on, it was ironically YHWH who helped the Pharaoh stick to his decision and will. All this led to the final showdown at the Red Sea. Only this would really solve the

73 That God realises his sovereign will through the desires of evil men is of course not a new idea, but was already stated by the church father Augustine. Cf. Alfred Adam, Die Zeit der Alten Kirche, vol. 1 of Lehrbuch der Dogmengeschichte, ed. Alfred Adam, 3rd ed. (Gütersloh: Gütersloher Verlagshaus, 1977), 274-275. 
problem and eliminate the danger of Pharaoh coming after the Israelites as they wandered through the wilderness. ${ }^{74}$

Nevertheless it is important to note that nowhere do we find God doing something to Pharaoh against his will. He does not "harden" the "heart" of Pharaoh so that he is unable to repent. God does not, as Enns believes, "prevent Pharaoh from acting in such a way as to save his own neck and the neck of his kingdom." 75 He will not "dictate Pharaoh's response." "76 Fischer and Markl write, "Gott hebt nicht das freie Handeln des Pharao auf, sondern stellt sich ihm, seinem Machtanspruch und vielfachen Unrecht entgegen."77

\section{THE "FAT" HEART IN ISAIAH}

We will now turn to the passage in Isa 6:9-10. We will not debate whether or not this chapter depicts the general calling of the prophet Isaiah, which would be odd after five chapters of prophetic message, or a special calling. What is clear is that the final redactor of Isaiah thought that this chapter was placed well in this context. It is therefore important to observe the chapters that immediately follow and the messages Isaiah is proclaiming there if we want to understand what is meant in our passage.

After the great vision of God that Isaiah experienced, and the cleaning of his lips with a burning coal from the altar, God explains the call of Isaiah with these words:

${ }^{9}$ And he replied: Go and say to this people: Listen carefully, but do not understand! Look intently, but do not perceive! ${ }^{10}$ Make the heart of this people sluggish (literally: fat), dull (literally: heavy) their ears and close (literally: blind) their eyes; lest they see with their eyes, and hear with their ears, and their heart understand, and they turn and be healed (Isa 6:9-10).

74 Durham writes: “The report of Yahweh to Moses that Pharaoh's mind is כבד 'heavy and dull,' quite literally like a lump of lead, must be understood, in the context of the mighty act sequence and indeed in the contest of the anticipation of that sequence, to be more than a mere announcement of additional difficulty. Every reference to the stubborn, obstinate, dull, hardened mind of Pharaoh must be seen against the backdrop of the entire mighty-act sequence, and every one of them, if only by general implication, reflects Yahweh's involvement." Durham, Exodus, 97.

75 Enns, Exodus, 130.

76 Enns, Exodus, 131.

77 Fischer, Markl, and Dohmen, Exodus, 75. Cf. also Werner H. Schmidt, Exodus 1: Exodus 1-6, BKAT II/1 (Neukirchen: Neukirchener Verlag, 1988), 213. 
The question we want to look at, is what was meant by this mission that Isaiah was commanded to fulfil? What does a "fat heart," a "heavy ear" and a "blind eye" mean and what exactly was the task that was expected from Isaiah?

\section{$1 \quad$ The Meaning of Isaiah 6:10}

Most commentaries understand these three aspects of Isaiah's mission negatively. They more or less agree with Franz Delitzsch, who wrote in 1879: "Es sind drei bildliche Ausdrücke des Begriffs der Verstockung ..."78 $\mathrm{He}$ understands the "fat heart" as a symbol of being insensitive for God's grace, the "heavy ears" as being deaf to God's words and the "bleary eyes" as eyes pasted over with a sticky secretion during the night so that they cannot be used to see God's deeds. ${ }^{79}$ Otto Kaiser similarly writes:

Statt das Herz des Volkes für Gott aufzuschließen, seine Ohren und Augen zu öffnen, soll er jenes verfetten lassen, so daß es noch träger seinen alten Takt schlägt, und diese schwerhörig machen, Sach 7,11, und verkleben 32,3. Sinne und Verstand des Volkes sollen in seinem Wirken und seinen Worten Gottes Ruf nicht wahrnehmen, und so muß es selbst, - das ist die unausgesprochene Konsequenz von V. $10 \mathrm{~b}$-, dahinsiechen und am Ende sterben. ${ }^{80}$

John Oswalt writes: "The faculties of perception and response (eyes, ears, and heart) will be dulled and apathetic," 81 and "A 'fat heart' speaks of a slow, languid, self-oriented set of responses, incapable of decisive, selfsacrificial action." 82

As previously mentioned, Röhser believes that the Exodus narrative and Isa 6:10 represent two different models of "hardening." He understands the Exodus narrative as a model of antecedent hardening ("vorgängige Verstockung"), ${ }^{83}$ which means that God hardened the heart of Pharaoh before Pharaoh did something to deserve this. We have already questioned this understanding. The passage in Isaiah, in his view, is a model of hardening after an event ("nachgängige Verstockung"), ${ }^{84}$ God is reacting on the refusal of his people to hear. In this way Röhser understands the terms in Isa 6:10 as making the organs of perception repellent and dull for everything which might lead to

78 Franz Delitzsch, Jesaja, 3rd ed. (Giessen: Brunnen-Verl., 1984), 103.

79 Delitzsch, Jesaja, 103.

80 Otto Kaiser, Der Prophet Jesaja: Kapitel 1-12, 5th ed., ATD 17 (Berlin: Evangelische Verlagsanstalt, 1984), 133.

81 John N. Oswalt, The Book of Isaiah, NICOT 19/1 (Grand Rapids, MI: Eerdmans, 1988), 189.

82 Oswalt, Isaiah, 189, fn. 10. Cf. also Helmer Ringgren, "šcemcen," in: Botterweck/Ringgren, ThWAT, Vol. 8: 254.

83 Röhser, Prädestination, 41.

84 Röhser, Prädestination, 55. 
understanding and healing: "Wer sich selbst verstockt, dessen Verstockung vollendet Gott." 85

There is one problem, however, that is usually not addressed in the commentaries that understand the terms in this way, namely how was Isaiah to fulfil this task? What can he do to make the heart fat, make the ear dull and blind the eyes? There is an active part of the messenger "in hardening and dulling, so that repentance will not take place," as John Watts pointed out. ${ }^{86}$ But what exactly is the active part?

Again, one of the problems in this passage is that we tend to understand the terms from our own understanding of the symbolic language. We assume to understand what a "fat heart" is (especially when our doctor tells us we need to lose weight!). We only understand a "fat heart" as meaning something unhealthy and bad. Being "fat" implies something completely negative. However, if we look into the OT, we find a totally different attitude where fat has a very positive association.

Kellenberger points out that there is no evidence in the whole OT that fat leads to insensitivity. ${ }^{87}$ Almost throughout the whole OT fat has a positive connotation. Kellenberger writes: "An keiner einzigen der insgesamt 190 Stellen meint das Substantiv šämän etwas Negatives," 88 and, "Das Alte Testament sieht, im Unterschied zu unserm heutigen Lebensgefühl, Fülle und Fett ungebrochen positiv." 89 One example of this can be found in Judg 3:29, where the Moabites are called "vigorous and strong" (NIV). The Hebrew reads

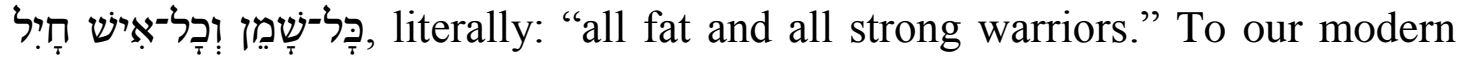
understanding a fat and strong warrior is an oxymoron.

What then does it mean to "make the heart fat"? In light of the positive connotation of fat, the Isaiah passage can, as Kellenberger claims, only mean something pleasant. ${ }^{90} \mathrm{~A}$ "fat heart" does not mean a heart that is immoveable because of its unhealthy fatness. Rather it is a heart that has everything it needs and wants and therefore does not feel a need to change. The end result may still be negative: there is no need of change, no need to respond positively to the

85 Röhser, Prädestination, 58. Cf. also Gary V. Smith, Isaiah 1-39, NAC 15/1 (Nashville, TN: B \& H Publ. Group, 2007), 195.

86 John D. W. Watts, Isaiah 1-33, WBC 24 (Waco, TX: Word Books / Nashville: Nelson, 1985), 75.

87 He showed this in his article, Edgar Kellenberger, "Heil und Verstockung: Zu Jes 6,9f bei Jesaja und im Neuen Testament," TZ 48 (1992): 268-75.

88 Kellenberger, "Heil und Verstockung," 269.

89 Kellenberger, "Heil und Verstockung," 270.

90 Kellenberger, "Heil und Verstockung," 270. Beuken has pointed out that the word הַשְׁמן alludes to the passages where Isaiah accuses the people of their careless prosperity (Jer 10:16; 17:4; 28;1, 4; 57:9). Cf. Beuken, Jesaja 1-12, 176. 
call to repent. The reason however is different. It is not because the heart simply cannot respond but because it does not want to and feels no need to. As we will see, the "making fat" of the heart was achieved through Isaiah's positive proclamation of salvation as described in the next chapter.

The second picture Isaiah uses fits this positive identification. Isaiah is to make the ears "heavy." The Hebrew word used here is the same as in the Exodus narrative: כבד It is also the same root used for the nouns "honour" and "glory" which appears a few verses earlier (Is 6:3), when the seraphim praise the "glory" of the Most High. Isaiah's call is to proclaim this very greatness and glory of God to Judah. Proclaiming the כָּבוֹד of YHWH will make the ears of

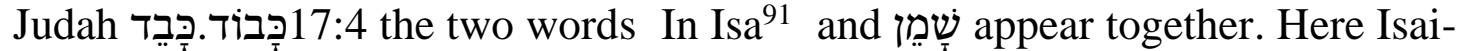

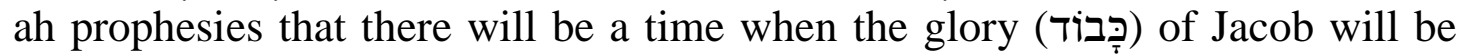
gone (literally: "be low") and the fat (מִשְָׁׁ) of his flesh will be lean. Although there is no mention of the ears here, this is another example of where Isaiah uses both roots together in one verse. It also again underlines the positive understanding of fatness by Isaiah.

In light of this we could say that the "heavy ears" are ears which have heard good things so that they feel there is no need to change anything; no need to repent. We may think of an honourable and important person who is so used to hearing flattering words that there seems to be no need to hear what God wants to say.

However, what do we make of the last picture: "blind their eyes"? There are actually two different roots which could be at play here: שעעשע שעע means "to be blind," שעשע means "to delight."93 Both roots are not very common in the OT. All occurrences of שעשע are in either pilpal, polpel or hithpolpel. שעע occurs once in qal (Isa 29:9), twice in hiphil (Isa 6:10 and Ps 39:14, where it cannot actually be translated as to "make blind" but to "look away") and once in hithpalpel (Isa 29:9). This last occurrence is especially interesting:

Stupefy yourselves and stay stupid; blind yourselves and stay blind! You who are drunk, but not from wine, who stagger, but not from strong drink!

The first phrase ("stupefy yourselves and stay stupid") literally reads: "Tarry and be astounded." Although some translations use the same words, the

91 Kellenberger, "Heil und Verstockung," 271.

92 Gesenius believes that שעשע is derived from a verb with only two consonants: שעע (Gesenius et al., Handwörterbuch, 1400), whereas Kellenberger believes that it is derived from two different roots, שעע I שעע II (Kellenberger, "Heil und Verstockung," 271, comp. also HAL 1489-1490).

93 Gesenius et al., Handwörterbuch, 1397, 1400. 
Hebrew words are different, but very similar. The first verb is מהקה, the second is תמה. The second phrase ("blind yourselves and stay blind") contains the only occurrence of שעע in hithpalpel and a form of שעעע in qal. Could it be that the first verb does not come from שעעש but שעע burom in which case the second phrase would mimic the first by using two very similar verbs. The meaning would then be: "delight yourselves and stay (or: be) blind." The previous verse speaks of a man who only dreams of eating or drinking but stays hungry and thirsty. The above translation would fit well in this context.

The point that is being made here is that Isaiah is playing on the similarity of the roots שעשע in 29:9. What if he is also playing on the ambiguity of these roots in 6:10, the passage we are discussing? This is exactly what Kellenberger assumes. ${ }^{94}$ This would mean that Isaiah is being told to delight the eyes of the people of Judah and in doing so to make them blind to that, which is really needed: repentance.

\section{Application}

If we look into the immediate context of Isa 6 we can see how this making the heart of the people of Judah fat, making their ears heavy and making their eyes blind worked. In chs. 7 and 8 we read about the encounter between Isaiah and king Ahaz. Rezin king of Aram and Pekah king of Israel marched up to fight against Jerusalem. In this dangerous situation Isaiah was sent to king Ahaz with a message of salvation. In three augmenting speeches $(7: 3-9 ; 7: 10-16 ; 8: 1-8 \mathrm{a})$ he presented a message of salvation for Judah without any condition on the side of Ahaz or the people. God will save Ahaz and Judah from the impending danger. He even offered Ahaz a sign (the young women which will conceive and give birth to a son called "Immanuel"; Isa 7:14) 95 to assure him that this salvation was going to come.

However, imbedded in Isaiah's message of salvation is another message, one of a coming judgment (7:17-25). God promises that he will remove the immediate threat of the Syria-Israelite kings which makes Ahaz and the people of Judah blind to the greater threat yet to come: that of Assyria. Ahaz does not respond to the warning. He does not repent from his wrong ways; there is no sign of realizing the threat of the coming judgment of God. Their heart was fat, their ears were heavy and their eyes did not see what was really important: repentance! They felt secure because God promised to save them. Are they not the people of God and have the temple in their midst? Why would they need to respond to a message of salvation with repentance? Hearing the message of salvation led them to ignore the message of judgment which Isaiah also

\footnotetext{
94 Kellenberger, "Heil und Verstockung," 271.

95 There is no place here to go into the discussion if this "young woman" is a virgin and if this sign is (also) meant as a prophecy of the virgin birth of Jesus.
} 
proclaims (Isa 7:17-25). In this way it is exactly the positive message of salvation that leads to the hardening of the heart of Judah. ${ }^{96}$

For instance, as Longman and Garland point out, we may therefore see a parallel here with how God's hardening of Pharaoh's heart is presented together with Pharaoh's hardening of his own heart in the Exodus narrative. ${ }^{97}$

This understanding of Isa 6:10 correlates with the NT passages which cite or refer to this text (Matt 13:14-15; Mark 4:12; Luke 8:10; John 12:40; Acts 28:26-27; Rom 11:8). In all of these passages it is the good news of the Gospel which leads to the hardening of the heart and finally to the judgement which comes through the refusal to hear God's word and repent. ${ }^{98}$ The people could hear, but they refused to do so; they could see, but they did not want to; they could understand, but they closed their hearts and minds to the Gospel. ${ }^{99}$

\section{E THE "HARDENING" IN THE BOOK OF JEREMIAH}

Jeremiah uses a special term which outside of this book only appears in Deut

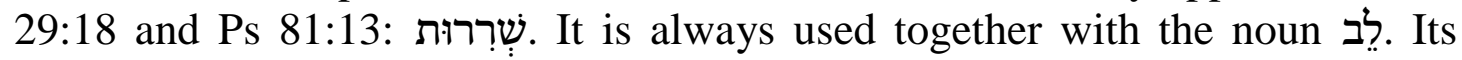
basic meaning is that of something being strong and hard, and since it is combined with the "heart," most translations render it as "stubbornness" or "obduracy." 100

Since this term only occurs in this special form and has no related words in the Hebrew OT, it is difficult to really understand its meaning. Fabry and Van Meeteren show that the etymology leads to the translation of "stubbornness" or "obduracy," but that there are also other possibilities. With a full holem instead of a shureq it could be a feminine plural form (שֶׁרְרוֹ) in the sense of "insinuations of the heart." 101 Fabry and Van Meeteren refer to Spencer who shows that it could also be understood in the sense of the (elusive) self-reliance of humans. ${ }^{102}$ They therefore conclude:

96 Kellenberger, "Heil und Verstockung," 272-274.

97 Tremper Longman and David E. Garland, Proverbs - Isaiah, ExBC 6 (Grand Rapids, MI: Zondervan, 2012), 509.

98 Kellenberger, "Heil und Verstockung," 274.

99 In Matthew, Mark and Luke Jesus speaks about the function of parables. A parable can be very ambiguous. It can uncover the truth (e.g. Matt 21:45) and at the same time mantle it (e.g. Mark 4:12) depending on the willingness of the receiver. It is easy to pretend to not understand a parable.

100 Gesenius et al., Handwörterbuch, 1413. Cf. also Helmut Lamparter, Prophet wider Willen: Der Prophet Jeremia, 3rd ed., BAT 20 (Stuttgart: Calwer, 1982), 58.

101 Heinz-Josef Fabry and Nele van Meeteren, "še rirût," in: Botterweck/Ringgren, ThWAT Vol. 8: 478.

102 Fabry and Van Meeteren, "še rirût," 478. 
Insofern zeige šerirût le $\underline{b}$ eine semantische Ambivalenz: für den Menschen selbst konsequente Standhaftigkeit, im Blick auf die Beziehung Mensch - Gott jedoch Halsstarrigkeit. ${ }^{103}$

Fischer also points out this ambiguity of the term and then concludes: "Basically it means in all passages a behaviour, where the centre of a human being ('heart') opposes God in an obstinate and stubborn way."104 The same can be found in the commentary of Holladay on Jeremiah. Holladay writes:

The noun שִשרִרוּת, occurring often in Jer ..., is normally translated "stubbornness." But it may not necessarily imply unreasonable obstinacy: the $N J V$ has "willfulness," the $J B$ (perhaps influenced by $G)$ has "dictates" and a recent study suggests "self-reliance." 105

If we look at Deut 29:18 we can easily see that "stubbornness" is not always the best translation. Let us take for example the New American Bible:

... if any such persons, after hearing the words of this curse, should congratulate themselves, saying in their hearts, "I am safe, even though I walk in stubbornness of heart," thereby sweeping away moist and dry alike, ...

It sounds somewhat strange that anyone would really think that he is safe when he walks in the stubbornness of his heart! It is also strange to translate the Hebrew preposition יפ, which links the two sentences, with "even though." The whole statement is one of self-reliance. It would therefore fit much better into the context to translate it as: "I am safe, because I walk in the self-reliance of my heart." This "self-reliance" is of course stubbornness in its effect because it hinders the person to listen to God and change his life according to God's word.

When we examine the other passages using the term שִרִרוּו, we find the same ambiguity in all verses (Ps 81:13; Jer 3:17; 7:24; 9:13; 11:8; 13:10; $16: 12 ; 18: 12$ and $23: 17)$. In five of the eight instances in Jeremiah we also find the adjective "evil" added to the heart. It is the self-reliance/stubbornness of the evil heart that Jeremiah accuses. Fischer thinks that Jeremiah took his phrase from Deut 29:18 but accentuated it with the word "evil." In his opinion the idea of a heart inclined to evil could go back to the Flood narrative, where we find this idea twice (Gen 6:5 and 8:21). ${ }^{106}$

103 Fabry and Van Meeteren, "še rirût," 478.

104 Georg Fischer, Jeremia 1-25, HThKAT 21/1 (Freiburg im Breisgau: Herder, 2005), 196.

${ }^{105}$ William L. Holladay, Jeremiah: A Commentary on the Book of the Prophet Jeremiah: Chapters 1-25, Hermen 24/1 (Philadelphia, PA: Fortress Press, 1986), 121.

106 Fischer, Jeremia 1-25, 195. 
Even if we do not follow these ideas we should notice that none of the passages where שִׁרִרוּת is is used implies any activity on the part of God. Therefore we should not use words like "hardening" which of course would

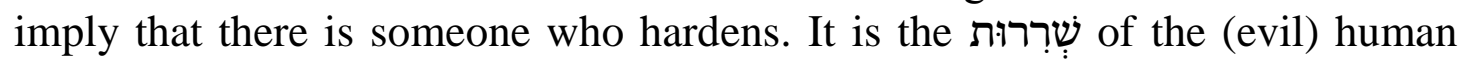
heart (i.e. the centre of his decision, mind and will) which is accused by the prophet. Maybe "hardness" could be a good translation for this Hebrew word because it simply stresses the fact itself.

\section{F CONCLUSION}

We have looked at three sections in the OT in which the theme "hardening of the heart" is usually identified: The Exodus narrative in the book of Exodus, the calling of the prophet Isaiah in Isa 6:9-10 and the book of Jeremiah. They all show how difficult it is to translate metaphorical language. It is not enough to know the correct "translation" of a phrase. It is much more important to ask what the author of the text and his first-hand-readers understood when using these metaphors.

Since all of this has to do with the "heart," we started by examining the meaning of this anthropological term. Unlike many modern cultures (especially those which have been influenced by Western thinking), the Bible understands the "heart" to mean the centre of the decision, will and mind of the human being.

This "heart" can become "strong," as we find in many passages in Exodus. A "strong will" is not negative in itself. It becomes negative when it is placed in opposition to the will of God. In the Exodus narrative it is Pharaoh himself whose will is strong to not let the people of Israel go. Only later in the story do we also read that God strengthened this will of Pharaoh in order to help him follow through with his decision. The will of Pharaoh was also "heavy," so that it could not be easily swayed. And as the plagues continued, intensified and also became heavier, God helped Pharaoh's will to remain steadfast. But nowhere do we read about God doing something to Pharaoh against his will. He never intervened and changed the Pharaoh's decision or forced him to do something he did not want.

We than turned to the text in Isa 6:10, a verse which is cited or referred to frequently in the NT. Again we saw that it does not help to understand the biblical metaphorical language using the understanding we have in today's society. A "fat" heart is not something negative. Rather it is the heart of someone who has everything he or she wants or needs - and therefore does not see any need to change direction. By addressing king Ahaz and the people of Judah with a message of salvation regarding the enemies at hand, Isaiah achieved the goal God wanted: to make the heart of Ahaz and his people fat so that they would continue in their ways. Likewise, the message of salvation made their ears heavy. They felt that they had everything. Nothing was 
missing. And finally their eyes reacted similarly. When they saw the sign God was giving them, they delighted and did not "see" any necessity to change. It was, therefore, the good news, the "gospel," of Isaiah which ironically led to the stubbornness of the people.

Finally we examined a word that apart from two instances (Deut 29:18 and Ps 81:13) is only used by Jeremiah to describe the stubbornness of the people of Israel: שִׁרִרוּת. As was the case with the terms used in both the Exodus narrative and in Isa 6:10, this word also contains the same ambiguity. It can be understood as something positive (self-reliance) that can turn into something negative (stubbornness) when it is used against God and his will.

We may therefore conclude that all the OT passages that refer to what is usually called "the hardening of the heart" contain the same ambiguity. They all describe something basically positive that becomes negative when turned against God and his will.

Should we then continue to use the terminology of "hardening of the heart" or "obduracy" in these contexts? I suggest we should not, since they insinuate that God has done something against the human will, forcing someone to do something they do not want to do or hindering them from something they do want. It is as Kaiser has pointed out concerning the Exodus narrative: "God is not the author of evil. There is no suggestion in Exod 4-14 that he secretly influenced Pharaoh's will or forced a stubborn resolution, which otherwise was incompatible with Pharaoh's basic nature and disposition." 107 Instead we could speak of "strengthening the heart" or "making firm the human decision."

\section{BIBLIOGRAPHY}

Adam, Alfred. Die Zeit der Alten Kirche. Vol. 1 of Lehrbuch der Dogmengeschichte. Edited by Alfred Adam. 3rd ed. Gütersloh: Gütersloher Verlagshaus, 1977. .

Assmann, Jan. "Zur Geschichte des Herzens im Alten Ägypten.” Pages 81-113 in Die Erfindung des inneren Menschen: Studien zur religiösen Anthropologie. Edited by Jan Assmann. SVfR 6. Gütersloh: Gütersloher Verl.-Haus Mohn, 1993.

Beuken, Willem A. M. Jesaja 1-12. HThKAT 19/1. Freiburg im Breisgau: Herder, 2003.

Botterweck, G. Johannes and Helmer Ringgren, eds. Theologisches Wörterbuch zum Alten Testament. (ThWAT) 10 vols. Stuttgart, u.a.: Kohlhammer, 1973-2000.

Delitzsch, Franz. Jesaja. 3rd ed. Giessen: Brunnen-Verl., 1984.

Dohmen, Christoph. Exodus 1-18. Edited by Erich Zenger and Ulrich Berges. HThKAT 2/1. Freiburg: Herder, 2015.

Durham, John I. Exodus. WBC 3. Waco, TX: Word Books, 1987.

Enns, Peter. Exodus. NIVAC. Grand Rapids, MI: ZondervanPublishingHouse, 2000.

107 Walter C. Kaiser, Toward Old Testament Ethics (Grand Rapids, MI: Zondervan Publ. House, 1983), 256. 
Fischer, Georg. Jeremia 1-25. HThKAT 21/1. Freiburg im Breisgau: Herder, 2005.

Fischer, Georg, Dominik Markl, and Christoph Dohmen. Das Buch Exodus. Edited by Christoph Dohmen. NSKAT 2. Stuttgart: Verl. Kath. Bibelwerk, 2009.

Gesenius, Wilhelm, Rudolph Meyer, Herbert Donner, Udo Rüterswörden, and Johannes Renz. Hebräisches und aramäisches Handwörterbuch über das Alte Testament. 18th ed. Berlin: Springer, 2013.

Gunn, David M. “The 'Hardening of Pharaoh's Heart': Plot, Character and Theology in Exodus 1-14." Pages 72-96 in Art and Meaning: Rhetoric in Biblical Literature. Edited by Alan J. Hauser, David J. A. Clines and David M. Gunn. JSOTSup 19. Sheffield: JSOT Press, 1982.

Hesse, Franz. Das Verstockungsproblem im Alten Testament: Eine frömmigkeitsgeschichtliche Untersuchung. BZAW 74. Berlin: Töpelmann, 1955.

Holladay, William L. Jeremiah: A Commentary on the Book of the Prophet Jeremiah: Chapters 1-25. Hermen 24/1. Philadelphia Pa.: Fortress Press, 1986.

Kaiser, Otto. Der Prophet Jesaja: Kapitel 1-12. 5th ed. ATD 17. Berlin: Evanglische Verlagsanstalg, 1984.

Kaiser, Walter C. Toward Old Testament Ethics. Grand Rapids, MI: Zondervan Publ. House, 1983.

. "Exodus." Pages 335-561 in Genesis - Leviticus. Edited by Tremper Longman and David E. Garland. ExBC 1. Grand Rapids, MI: Zondervan, 2008.

Keil, Carl F. Genesis und Exodus. 3rd ed. Giessen u. a.: Brunnen-Verl., 1983.

Kellenberger, Edgar. "Heil und Verstockung: Zu Jes 6,9f bei Jesaja und im Neuen Testament." TZ 48 (1992): 268-75.

. "Theologische Eigenarten der Verstockung Pharaos in Exod 4-14." TZ 58 (2002): 109-13.

. Die Verstockung Pharaos: Exegetische und auslegungsgeschichtliche Untersuchungen zu Exodus 1 - 15. BWANT 171. Stuttgart: Kohlhammer, 2006.

Köhler, Ludwig and Walter Baumgartner. Hebräisches und aramäisches Lexikon zum Alten Testament. 3rd ed. Leiden: Brill, 2004.

Lamparter, Helmut. Prophet wider Willen: Der Prophet Jeremia. 3rd ed. BAT 20. Stuttgart: Calwer, 1982.

Lauha, Risto. Psychophysischer Sprachgebrauch im Alten Testament: Eine strukturalsemantische Analyse von רוח und נפש לב Helsinki: Suomaleinen Tiedeakademia, 1983.

Longman, Tremper, and David E. Garland. Proverbs - Isaiah. 13 vols. ExBC 6. Grand Rapids, MI.: Zondervan, 2012.

Oswalt, John N. The Book of Isaiah. NICOT 19/1. Grand Rapids, MI: Eerdmans, 1988.

Propp, William H. C. Exodus 1-18: A New Translation with Introduction and Commentary. 1st ed. AYB 2. New Haven: Yale Univ. Press, 2010.

Röhser, Günter. Prädestination und Verstockung: Untersuchungen zur frühjüdischen, paulinischen und johanneischen Theologie. TANZ 14. Tübingen: Francke, 1994.

Schmidt, Werner H. Exodus 1: Exodus 1-6. BKAT II/1. Neukirchen: Neukirchener Verlag, 1988. 
Smith, Gary V. Isaiah 1-39. The New American Commentary 15/1. Nashville, TN: B \& H Publ. Group, 2007.

Stendebach, Franz J. Der Mensch ... wie ihn Israel vor 3000 Jahren sah. Stuttgart: KBW Verlag, 1971.

Stuart, Douglas K. Exodus. NAC 2. Nashville: B\&H Publishing Group, 2006.

Utzschneider, Helmut, Wolfgang Oswald, and Shimon Gesundheit. Exodus 1-15: Deutschsprachige Erstausgabe. 1st ed. IEKAT 2/1. Stuttgart: Kohlhammer Verlag, 2013.

VanGemeren, Willem, ed. New International Dictionary of Old Testament Theology and Exegesis. 5 vols. Carlisle, Cumbria: Paternoster Press, 1996.

Von Meyenfeld, Frederik Hendrik. Het Hart (Leb, Lebab) in het Oude Testament. Leiden: Brill, 1950.

Watts, John D. W. Isaiah 1-33. Word Biblical Commentary 24. Waco, TX: Word Books / Nashville: Nelson, 1985.

Wolff, Hans W., and Bernd Janowski. Anthropologie des Alten Testaments. Mit zwei Anhängen neu herausgegeben von Bernd Janowski. 1st ed. Gütersloh:

Gütersloher Verl.-Haus, 2010.

Dr. Hans-Georg Wünch is lecturer and academic dean at the Theologisches Seminar Rheinland (TSR - Rhineland School of Theology) in Wölmersen, Germany, lecturer of Biblical Hebrew at the Theologische Hochschule Ewersbach (THE) in Ewersbach, Germany, and Research Fellow at the Department of Biblical and Ancient Studies at the University of South Africa (UNISA) in Pretoria, South Africa.Email: hans-georg.wuench@tsr.de. 